Research Article

\title{
Difference of Vertical Transmission in HIV-Infected Women with Complete and Incomplete PMTCT
}

\section{PerbedaanTransmisi Vertikal pada Ibu Hamil HIV Positif dengan Prevention Maternal to Child Transmission (PMTCT) Lengkap dan Tidak Lengkap}

\author{
Sitti Fausihar, Yudianto B Saroyo \\ Department of Obstetrics and Gynecology \\ Faculty of Medicine University of Indonesia/ \\ Dr. Cipto Mangunkusumo Hospital \\ Jakarta
}

\begin{abstract}
Objective: To analyze any differences on vertical transmission in groups with complete and incomplete program as well as the factors influencing completion.

Method: This was a retrospective cohort study performed by data collection from medical records and/or interviews from January 2010 to February 2012. The variables analyzed subject characteristics, applied PMTCT program and risk factors affecting transmission.

Result: Seventy-five pregnant women who were HIV-positive were initially recruited, but 21 subjects were excluded due to incomplete medical records. In the first group $(n=27)$ who received complete PMTCT, no vertical transmission was identified, while in the second group ( $\mathrm{n}=27$ ) with incomplete PMTCT, seven children were found to be HIV-positive. Rupture of membrane for more than 4 hours was the only significant risk factor for vertical transmission $(\mathrm{p}=0.001$, $\mathrm{RR}=64.5,95 \% \mathrm{CI}=6.14-677.6)$.

Conclusion: There was a significant difference in the occurrence of vertical transmission between complete and incomplete PMTCT program. Complete PMTCT program may provide protective effect against the occurrence of vertical transmission by $25.9 \%$.

[Indones J Obstet Gynecol 2015; 2: 69-75]

Keywords: HIV, PMTCT, vertical transmission
\end{abstract}

\begin{abstract}
Abstrak
Tujuan: Untuk mempelajari perbedaan transmisi vertikal pada anak dari ibu hamil dengan HIV positif pada PMTCT lengkap dan tidak lengkap, serta faktor-faktor yang mempengaruhinya.

Metode: Studi ini merupakan penelitian kohort retrospektif dengan mengambil data dari rekam medis dan/atau menghubungi ibu dengan HIV dari Januari 2010 sampai Februari 2012. Dikumpulkan karakteristik dari para subjek, program PMTCT yang dijalani dan faktor-faktor risiko yang dapat mempengaruhi transmisi vertikal.

Hasil: Terdapat 75 ibu hamil dengan HIV positif namun hanya 54 pasang ibu-anak (72\%) yang memiliki data lengkap. Pada 27 ibu hamil yang mendapat PMTCT lengkap tidak ditemukan transmisi vertikal, sedangkan pada 27 ibu hamil lainnya dengan PMTCT tidak lengkap ditemukan 7 anak yang positif HIV. Dengan regresi logistik didapatkan hanya ketuban pecah $\geq 4$ jam yang menjadi faktor risiko terjadinya transmisi vertikal $(p=0,001 ; R R=64,5 ; 95 \%$ IK 6,14-677,6).
\end{abstract}

Kesimpulan: Terdapat perbedaan kejadian transmisi vertikal yang bermakna antara perempuan yang menjalani PMTCT lengkap dan tidak lengkap. Dengan melakukan PMTCT lengkap dapat memberikan efek protektif terhadap terjadinya transmisi vertikal sebesar 25,9\%.

[Maj Obstet Ginekol Indones 2015; 2: 69-75]

Kata kunci: HIV, PMTCT, transmisi vertikal

Correspondence: Sitti Fausihar. Department of Obstetrics and Gynecology/Dr. Cipto Mangunkusumo Hospital, Jakarta. Email: ziung@yahoo.com

\section{INTRODUCTION}

According to the latest data from the World Health Organization (WHO), approximately 35.3 million people are currently living with the Human Immunodeficiency Virus (HIV), 30 million of which are living in lower-middle income countries, with approximately 2.3 million new infections in $2012 .{ }^{1}$ HIV transmission occurs through contact with infected blood, organ transplantation, needle sharing, unprotected sexual intercourse, and vertical transmission from mother to infant. The risk of HIV transmission to infants in mothers who do not carry out any intervention is estimated to be about $15-45 \%{ }^{2}$

The estimated risk of HIV transmission during pregnancy is $5-10 \%, 10-20 \%$ during labor, and 5$20 \%$ during breastfeeding. ${ }^{2,3}$ However, this can be lowered to less than $2 \%$ through antiretroviral prophylaxis given to the mother during pregnancy and child birth and the infants in the first weeks of life, as well as obstetrical interventions including elective cesarean surgery and avoidance of breastfeed- 
ing. These interventions are known as the Prevention of Maternal To Child Transmission (PMTCT) or the prevention of mother-to-child vertical transmission. ${ }^{1,4}$ Transmission to the child can be evaluated after 18 months of age, when anti-HIV antibodies that were transferred from the mother become undetectable. However, the evaluation can also be performed before 18 months by detecting viral DNA or RNA, viral culture, and IgA antibodies against HIV. 4

In Indonesia, the proportion of HIV cases in women increased from 34\% in 2008 to $44 \%$ in 2011, leading to an increase in HIV and AIDS transmitted from mother to baby. The number of HIV cases in children aged 0-4 years increased from $1.8 \%$ in 2010 to $2.6 \%$ in the following year. ${ }^{4}$ Directorate General of Disease Control of the Indonesian Ministry of Health has developed a prevention program called "Pencegahan Penularan HIV dari Ibu ke Anak" (PPIA). Saroyo et $\mathrm{al}^{5}$ has conducted a descriptive study in Dr. Cipto Mangunkusumo Hospital (RSCM) from January 2006 to December 2009 with the results of $174 \mathrm{HIV}$-positive pregnant women, but the HIV status of the baby is known in only 52 of them, and all were declared negative. They also revealed the difficulty to collect complete and sufficient data, and thus becoming a major bottleneck in the tracing of PMTCT data in RSCM.

The lack of integration of existing record system in Pokdisus HIV/Acquired Immune Deficiency Syndrome (AIDS), Department of Obstetrics and Gynecology, and Department of Pediatrics, causes difficulty in synchronizing data related to mother-tochild transmission during pregnancy, childbirth, and post-partum. In Indonesia, there is still limited data for vertical transmission, and also the number of HIV-infected pregnant women is likely to increase. Therefore, this study was conducted in order to assess the PMTCT program to see the outcome of vertical transmission in children from HIVinfected pregnant women during the period of January 2010-February 2012 at RSCM, which is expected to be a reflection of the government's effort to decrease the number of people living with HIV in Indonesia.

\section{METHODS}

Our study design is a retrospective cohort comparing vertical transmission of HIV occurring in infants born to HIV-positive pregnant women who received complete and incomplete PMTCT. It was conducted by collecting medical records of pregnant women who presented to the ER/delivery room and obstetrics outpatient clinic from January 2010 to February 2012, as well as the medical records of infants born from HIV-positive mothers from January 2010 to February 2012 and presenting to the pediatrics clinic or emergency room in RSCM. All the datas have to meet the inclusion and exclusion criteria.

The inclusion criteria are medical records of HIV-positive pregnant women as confirmed with either HIV rapid tests, ELISA or western blot for HIV antibodies, or by the viral load; all subjects being treated at RSCM, either from ANC or in the ER/delivery room from January 2010 to February 2012 and/or infants who seek treatment in the pediatric outpatient clinic or emergency department of RSCM who were born from HIV-positive mothers between January 2010 and February 2012, and also data regarding maternal and infant has to be completely stated in the medical records.

Subjects will be excluded if there were any anomaly/congenital abnormalities in the infants, contra indication of antiretroviral prophylaxis, no result of HIV antibodies of infants older than 18 months of age, and also breastfeeding mothers who have had problems in the breast and/or sores in the infant's mouth.

Complete PMTCT in this study is achieved when the mother has taken the ARV for at least 4 weeks before pregnancy ${ }^{6}$, had underwent cesarean section, the infant has taken prophylactic ARV for 4-6 weeks, and had not been breastfed. PMTCT is considered incomplete when the subject does not meet one or more of the criteria of PMTCT.

Several risk factors have been stated to influence the occurrence of vertical transmission, which can be encountered during pregnancy such as high maternal viral load, sexually transmitted infections, maternal malnutrition; those encountered during childbirth, for example high maternal viral load, amniotic rupture $\geq 4$ hours, invasive procedure during delivery, chorioamnionitis and $\mathrm{CD}_{4}$ count; as well as breastfeeding. Those risk factors will also be analyzed.

This study was analyzed using SPSS 20.0 (IBM(C)) software. The independent variable was analyzed with unpaired categoric comparative analysis using Fisher's exact test. Confounding factors were analyzed using logistic regression. The ROC- 
AUC curve analysis was performed to rank the highest predictor for vertical transmission. All significant variables were then included for multivariate analysis using logistic regression, from which the odds ratio (OR) for each variables could be ranked. Validation of the formula was done by computing the ROC, AUC, and Hosmer-Lemeshow test.

\section{RESULTS}

There were 75 pregnant women with HIV from January 2010 to February 2012. Only $72 \%$ of all the mother-infant pairs fulfilled the inclusion and exclusion criteria, of whom 27 pairs had complete PMTCT and 27 pairs had incomplete PMTCT. Characteristics of the study participants classified by completion of PMTCT can be seen in Table 1.

Table1. Subject Characteristics

\begin{tabular}{|c|c|c|}
\hline Variable & Incomplete PMTCT n=27 (\%) & Complete PMTCT n=27 (\%) \\
\hline \multicolumn{3}{|l|}{ Maternal ARV } \\
\hline No ARV (<4 weeks) & $27(50.0)$ & 0 \\
\hline ARV prophylaxis & 0 & $13(24.1)$ \\
\hline Combination ARV (HAART) & 0 & $14(25.9)$ \\
\hline \multicolumn{3}{|l|}{ Mode of delivery } \\
\hline Vaginal delivery & $8(14.8)$ & 0 \\
\hline Emergency Caesarean section & $12(22.2)$ & $11(20.4)$ \\
\hline Elective Caesarean section & $7(13.0)$ & $16(29.6)$ \\
\hline \multicolumn{3}{|l|}{ Infant prophylactic ARV } \\
\hline No ARV & 0 & 0 \\
\hline ARV prophylaxis & $27(50.0)$ & $27(50.0)$ \\
\hline \multicolumn{3}{|l|}{ Breastfeeding } \\
\hline Yes & 0 & 0 \\
\hline No & $27(50.0)$ & $27(50.0)$ \\
\hline \multicolumn{3}{|l|}{$\mathrm{CD}_{4}$ count (mother) } \\
\hline$<200 \mathrm{cell} / \mathrm{mm}^{3}$ & $5(9.3)$ & $2(3.7)$ \\
\hline $200-350 \mathrm{cell} / \mathrm{mm}^{3}$ & $10(18.5)$ & $11(20.4)$ \\
\hline$>350 \mathrm{cell} / \mathrm{mm}^{3}$ & $10(18.5)$ & $14(2.0)$ \\
\hline Not examined & $2(3.7)$ & 0 \\
\hline \multicolumn{3}{|l|}{ Viral load (mother) } \\
\hline > 1000 copies $/ \mathrm{ml}$ & 0 & $2(3.7)$ \\
\hline$<1000$ copies $/ \mathrm{ml}$ & 0 & 0 \\
\hline Undetected & $5(9.3)$ & $4(7.4)$ \\
\hline Not examined & $22(40.7)$ & $21(38.9)$ \\
\hline \multicolumn{3}{|l|}{ Viral load (infant) } \\
\hline$>100.000$ copies $/ \mathrm{ml}$ & 0 & 0 \\
\hline$<100.000$ copies $/ \mathrm{ml}$ & 0 & $1(1.8)$ \\
\hline Undetected & $13(24.1)$ & 8 (14.8) \\
\hline Not examined & $14(25.9)$ & $18(33.3)$ \\
\hline \multicolumn{3}{|l|}{ ELISA (infant $\geq 18$ months) } \\
\hline Positive & $7(13.0)$ & 0 \\
\hline Negative & $20(37.0)$ & $27(50.0)$ \\
\hline
\end{tabular}




\begin{tabular}{|c|c|c|}
\hline Variable & Incomplete PMTCT n=27 (\%) & Complete PMTCT n=27 (\%) \\
\hline \multicolumn{3}{|l|}{ Pregnancy } \\
\hline Singleton & $27(50.0)$ & $27(50.0)$ \\
\hline Multiple & 0 & 0 \\
\hline \multicolumn{3}{|l|}{ Gestational age at delivery } \\
\hline 35-36 weeks & $4(7.4)$ & $6(11.1)$ \\
\hline 37 weeks & $23(42.6)$ & $21(38.9)$ \\
\hline \multicolumn{3}{|l|}{ Birth weight } \\
\hline$<2500$ gram & $3(5.6)$ & $4(7.4)$ \\
\hline$\geq 2500$ gram & $24(44.4)$ & $23(42.6)$ \\
\hline \multicolumn{3}{|c|}{ Sexually Transmitted Infections } \\
\hline Yes & $3(5.6)$ & 0 \\
\hline No & $24(44.4)$ & $27(50.0)$ \\
\hline \multicolumn{3}{|c|}{ Malnutrition (during pregnancy) } \\
\hline Yes & $5(9.3)$ & $2(3.7)$ \\
\hline No & $22(40.7)$ & $25(46.3)$ \\
\hline \multicolumn{3}{|l|}{ Membrane rupture } \\
\hline$\geq 4$ hours & $9(16.7)$ & $1(1.8)$ \\
\hline$<4$ hours & $18(33.3)$ & $26(48.2)$ \\
\hline \multicolumn{3}{|l|}{ Chorioamnionitis } \\
\hline Yes & 0 & 0 \\
\hline No & $27(50.0)$ & $27(50.0)$ \\
\hline \multicolumn{3}{|l|}{ Invasive procedure } \\
\hline Yes & 0 & 0 \\
\hline No & $27(50,0)$ & $27(50.0)$ \\
\hline
\end{tabular}

Table 2. The Relationship Between PMTCT and Vertical Transmission in Infants $\geq 18$ Months.

\begin{tabular}{lccccccc}
\hline \hline & \multicolumn{2}{c}{ Vertical transmission (+) } & \multicolumn{2}{c}{ Vertical transmission (-) } & p & cRR & 95\% CI \\
\cline { 2 - 6 } & $\mathrm{n}$ & $\%$ & $\mathrm{n}$ & $\%$ & & & \\
\hline Incomplete PMTCT & 7 & 25.9 & 20 & 74.1 & 0.010 & 0.741 & $0.593-0.926$ \\
Complete PMTCT & 0 & 0 & 27 & 100.0 & & & \\
Total & 7 & 13.0 & 47 & 87.0 & & \\
\hline
\end{tabular}

In this study, we performed unpaired categoric comparative analysis using Fisher's exact test, because Chi Square test requirement were not fulfilled. This study compares the vertical transmission of HIV in children of pregnant women with HIV who complete and do not complete PMTCT. The children HIV status was seen from ELISA exa- mination at age $\geq 18$ months. At the age of $<18$ months, the viral load may be examined using PCR, but not all the children had the examination because it was more expensive than ELISA. To measure the strength of the relationship and because this is a cohort study design, we also calculated the relative risk (RR). 
Table 2 shows there is a significant difference in vertical transmission between pregnant women receiving complete and incomplete PMTCT $(\mathrm{p}<0.05)$. Therefore, if we do complete PMTCT, it will provide a protective effect from vertical transmission of HIV in infants. The risk of vertical transmission was reduced by approximately $25.9 \%$ in patients with complete PMTCT $(\mathrm{RR}=0.741)$.

The confounding variables that will be analyzed include the viral load, sexually transmitted infections, malnutrition in mothers, membrane rupture $\geq 4$ hours, invasive procedure during delivery, chorioamnionitis and maternal CD4 cell count. Confounding variable of maternal viral load could not be analyzed because only nine subjects were examined, while maternal CD4 cell count during pregnancy cannot be analyzed either because the CD4 count for two subjects were not available. CD4 count can be analyzed by comparative analysis of numeric variables, but because the data distribution is not normal, the CD4 count can only be analyzed using non-parametric test.

Invasive procedures and choriamnionitis also can not be analyzed as there were no invasive procedures or chorioamnionitis in our samples. In multivariate analysis, only two variables were included, which were maternal malnutrition and amniotic membrane rupture. Sexual transmitted infection was excluded from the multivariate analysis because it does not meet the requirements with $\mathrm{p}>0.25$.

With the backward LR method in logistic regression, it was found that only rupture $\geq 4$ hours that have significant effect on vertical transmission in infants $\geq 18$ months. Rupture of membranes $\geq 4$ hours increased the risk 64 times compared to rupture of $<4$ hours. However, this risk needs to be analyzed further because the confidence interval was very wide.

\section{DISCUSSION}

We identified 75 pregnant women with HIV from January 2010 to February 2012, but were only able to include 54 women in our study due to incomplete data. We found that data in some medical records were not complete, suggesting pitfalls occurring at the time of registration and/or data entry. Some subjects had the wrong address, had moved, used a false identity to obtain insurance, or the possibility of a negative stigma because of the HIV causing the patient move out after delivery. This will affect the monitoring of ARV treatment and the effort to control HIV transmission, either horizontally or vertically. Women's program of the Asia Pacific network of people living with HIV, in a study with six Asian countries including Indonesia, has stated that the factors affecting access to health care for pregnant women with HIV-positive include a lack of knowledge and awareness, long distance to health facilities, the availability and costs (for transportation, services, laboratory tests, procedures, doctor and medication costs), the confidentiality of patient status and negative attitude coming from health service providers. ${ }^{7}$ Three cases in this study revealed that the problem of stigma and discrimination from health care providers causes reluctance to come back for treatment.

The majority of subjects (53.7\%) had graduated from senior high school, $22.2 \%$ graduated from junior high school, $16.7 \%$ have graduated university, and only $7.4 \%$ were elementary school graduates. In accordance with a 2001 report from UNAIDS stating that education plays an important role in predicting lifestyle adjustments; with higher level of education, exists a tendency to delay first sexual intercourse, and they will also be able to understand and react positively to the PMTCT program when they are pregnant. Three of the four subjects in this study only completed elementary school,with the tendency to be less concerned due to lack of understanding of HIV, which may also be influenced by the environment they live in, leading to a reluctance in following PMTCT. ${ }^{8}$

More than half of the subjects (59.2\%) did not work, 31.5\% had a stable job, and 9.3\% did not have a permanent job. A woman who does not work has bigger dependence on their partner, causing their position in the family to become very small, and making them more vulnerable to get HIV. This is consistent with the trend of increasing number of housewives contracting HIV from her husband. As much as $79.7 \%$ of women in this study were infected through sexual intercourse, mostly obtained from their husbands who obtained HIV through intravenous drug use or unprotected sexual intercourse. ${ }^{9}$

Not all subjects obtained HIV from their husbands, there were 17 subjects whose husband's HIV status was negative, and were infected from their previous husband or from needle use. Data from 27 cohort studies with a total of 13,061 se- 
rodiscordant couples in Sub-Saharan Africa as well as data from the Demographic and Health Survey with 1,145 serodiscordant couples in 14 countries concluded that $47 \%$ of heterosexual women with positive HIV status in a serodiscordant couple can remain in a good and stable relationship. ${ }^{10}$

In the complete PMTCT group, we did not find any children who were HIV-positive, while there were 7 children $(13 \%)$ with positive HIV status in the incomplete PMTCT group. From the Fisher's test, we concluded that significant differences in vertical transmission can be encountered in complete and incomplete PMTCT with an RR of 0.741.

From Table 3, we can see that two steps of PMTCT were not performed in the seven subjects above, including not taking anti retroviral drugs during pregnancy and having vaginal delivery. However, one subject in our study also did not perform the two steps but no vertical transmission was encountered. This is possibly due to a very low or undetectable amount of HIV virus in the subject, limiting chance of transmission. Unfortunately, no data exists on the exact amount of virus that can explain the differences in outcome. Briand et al have studied the influence of method of delivery on the occurrence of vertical transmission, with the conclusion that vaginal delivery does not increase the risk of vertical transmission of HIV when the amount of virus in the prenatal period is controlled, with values varying between $50-1,000$ copies $/ \mathrm{ml}^{11}$

Developed countries such as Canada have established a program to study the epidemic of vertical transmission in pregnant women by the name of the Canadian Perinatal HIV Surveillance Program (CPHSP), which was established in 1990 under the direction of the Canadian Pediatric AIDS Research Group. They performed data collection from the year 1990-2010 in all regions of Canada. The rate of transmission was only $0.4 \%$ when maternal HAART was initiated at least 4 weeks prior to delivery. Townsend et al also found the rate of vertical transmission in England and Ireland to be 0.8\% when HAART is given at least 2 weeks before birth, ${ }^{6}$ whereas in this study the administration of antiretroviral drugs during pregnancy is only $26 \%$, with no vertical transmission $(0 \%)$.

From the logistic regression analysis of the confounding factors, the only condition with significant influence on vertical transmission is membrane rupture longer than 4 hours. Unfortunately, the data distribution of membrane rupture $\geq 4$ hours is not normal, therefore we cannot observe the cut off point of time influencing the transmission, and only non-parametric test was performed. In Miami, a prospective cohort study with 717 subjects on rupture of membranes in pregnant women with HIV concluded that the perinatal transmission rate was $1 \%$ in women with membrane rupture for less than 4 hours and $1.9 \%$ when rupture occurred for 4 or more hours. For 493 women with a viral load of less than 1,000 copies/ml receiving combination ART in pregnancy, there were no cases of perinatal transmission identified for up to 25 hours of membrane rupture. Logistic regression demonstrated only viral load above 10,000 copies/ml as an independent risk factor for perinatal transmission $\left(\mathrm{p}<0.001, \mathrm{OR}=164.4,95 \%\right.$ CI 10.96-2,465.7). ${ }^{12}$

In this study, the viral load data of the subjects were not complete so we cannot perform the analysis. The subjects in this study cannot routinely get their viral load tested due to economic factor.

Table 3. Characteristics of HIV-Positive Children

\begin{tabular}{|c|c|c|c|c|c|c|c|}
\hline No & Gestational age & $\begin{array}{c}\text { Membrane } \\
\text { rupture (hour) }\end{array}$ & $\begin{array}{l}\text { Birth weight } \\
\text { (gram) }\end{array}$ & $\begin{array}{l}\text { Mother ARV } \\
\text { consumption }\end{array}$ & $\begin{array}{l}\text { Mode of } \\
\text { delivery }\end{array}$ & $\begin{array}{c}\text { Infant } \\
\text { prophylaxis } \\
\text { ARV }\end{array}$ & $\begin{array}{l}\text { Breast- } \\
\text { feeding }\end{array}$ \\
\hline 1 & $>37$ weeks & 0 & 3600 & No & Vaginal & Yes & No \\
\hline 2 & $>37$ weeks & 5 & 2900 & No & Vaginal & Yes & No \\
\hline 3 & $>37$ weeks & 10 & 2800 & No & Vaginal & Yes & No \\
\hline 4 & $>37$ weeks & 11 & 3100 & No & Vaginal & Yes & No \\
\hline 5 & $>37$ weeks & 6 & 2400 & No & Vaginal & Yes & No \\
\hline 6 & $>37$ weeks & 6 & 3300 & No & Vaginal & Yes & No \\
\hline 7 & $>37$ weeks & 8 & 2600 & No & Vaginal & Yes & No \\
\hline
\end{tabular}


Therefore, a prospective cohort should be conducted to make it easier to follow the subjects and do laboratory examination as desired by the researcher. However, this will require more funds than just taking data from the medical records.

This study found the incidence of HIV-negative children from HIV-positive mothers who completed PMTCT, with RR/OR $<1$, to indicate that complete PMTCT can be a protective factor towards the occurrence of vertical transmission in children. But the drawback of this study is the lack of samples, as our sample do not meet the minimum number. Thus, our study results can not be generalized and required further research with a larger sample. The limited number of sample is due to the limited time and the fact that data collection of HIV patients' medical records is still inefficient, so some people with HIV cannot be followed. Even though there are limitations, but this study affirms the prospect that doing PMTCT correctly can provide better outcome in terms of preventing vertical transmission.

At the International AIDS Society conference in July 2013, following a review of the available evidence, WHO issued a new set of ART guidelines recommending earlier initiation of ART at CD4 cell count of 500 cells/ml or less for all adults and children above 5 years. According to the 2013 treatment guidelines, WHO is targetting 15 million people with HIV to receive antiretroviral treatment and only 40,000 new cases of HIV in children in 2015 compared to 290,000 cases in 2012.13,14

The coverage of ARV recipients in Indonesia in 2009 was 3.8\%, similar to the coverage in Nepal (3.3\%), and far behind Cambodia (32.2\%), India $(17.4 \%)$ and Vietnam (32.3\%). ${ }^{7}$ It indicates that there is still much work to be done by the Ministry of Health to achieve the target set by WHO.

The results of this study may be used as an input for the Directorate General of Disease Control Ministry of Health in order to improve the coverage of PMTCT programs, improve data collection by developing a program as was done by the CPHSP in Canada, evaluate and improve the PMTCT program in Indonesia, help reduce the number of maternal and infant mortality due to HIV/AIDS and prepare the next generation with good and qualified children free from HIV.

\section{REFERENCES}

1. World Health Organization. New HIV recommendations to improve health, reduce infections and save lives. [Online]. Last updated in 2013. Available from: URL:http://www. medicalnewstoday.com/articles/172456.php.

2. De Cock K, Fowler M, Mercier E, et al. Prevention of motherto-child HIV transmission in resource poor countries. JAMA 2000; 283: 1175-82.

3. Kementerian Kesehatan Republik Indonesia. Pedoman nasional pencegahan penularan HIV dari ibu ke anak. $2^{\text {nd }}$ ed. Jakarta: Kementerian Kesehatan Republik Indonesia, 2012.

4. Townsend CL. Antiretroviral therapy and pregnancy outcome in HIV infected women in the United Kingdom and Ireland. London: University College London; 2009.

5. Saroyo YB. Karakteristik pelayanan pada ibu hamil dengan Human Immunodeficiency Virus (HIV) dalam program pencegahan transmisi vertikal ibu-anak di RSUPN Dr. Cipto Mangunkusumo, Jakarta tahun 2006-2009. Jakarta: Divisi Fetomaternal, Departemen Obstetri dan Ginekologi, Rumah Sakit Umum Pusat Nasional Dr. Cipto Mangunkusumo; 2011.

6. Forbes JC, Alimenti AM, Singer J, et al. A national review of vertical HIV transmission. AIDS 2012; 26(6): 757-63.

7. Women of the Asia Pacific Network of People Living with HIV. Positive and pregnant: how dare you. A study on access to reproductive and maternal helath care for women living with HIV in Asia. Reprod Health Matter 2012; 20(39): 1108.

8. United Nations Programme on HIV/AIDS (UNAIDS). Report on the global AIDS epidemic 2008. Geneva: UNAIDS; 2008.

9. Sibanda M. The characteristics of pregnant women attending the prevention of mother to child transmission of HIV (PMTCT) programme at Bulawayo city clinics, Zimbabwe. Dissertation. University of South Africa. 2008.

10. World Health Organization. Guidance on couples HIV testing and counseling including antiretroviral therapy for treatment and prevention in serodiscordant couples. Geneva: World Health Organization; 2012.

11. Briand N, Jasseron C, Sibiude J, et al. Cesarean section for HIV-infected women in the combination antiretroviral therapies era, 2000-2010. Am J Obstet Gynecol 2013; 209(4): 335.e1-12.

12. Cotter AM, Brookfield KF, Duthely LM, et al. Duration of membrane rupture and risk of perinatal transmission of HIV-1 in the era of combination antiretroviral therapy. Am J Obstet Gynecol 2012; 207: 482.e1-5.

13. Doherty M, Ford N, Vitoria M, et al. The 2013 WHO guidelines for antiretroviral therapy: evidence-based recommendations to face new epidemic realities. Curr Opin HIV AIDS 2013; (6)8: 528-34.

14. World Health Organization. 2013 WHO Consolidated ARV Guidelines, Summary of Major Recomendations and Estimated Impact. Geneva: World Health Organization; 2013. 